\section{The Duke and ZPG}

SIR,-You are quite right to stress that the rate of population growth is influenced by death rate as well as birth rate; and as you imply, people will not be persuaded to accept a decreased life expectancy. What you fail to appreciate is that this means that the only way of halting a still-increasing population is to reduce the birth rate sufficiently to compensate for the lower death rate. Such a policy would eventually result in a decrease in population, assuming constant fertility.

You are also ignoring the special problems of a nation like Britain which relies for its survival on imports. As world resources are depleted, and demand rises owing to increased population and industrialization, the pressures to become self-sufficient will grow. From this viewpoint, it is certainly arguable that Britain is overpopulated. As you suggest, the superficial evidence of crowded towns is not enough to go on. One needs a criterion for deciding if a nation is overpopulated, and we suggest that if a country's material and agricultural resources are insufficient to give it a reasonable degree of independence then its population is too large. By this criterion, of course, Britain has far too many people.
Next, we should like to point out the mistake of isolating population as a factor affecting the quality of life. Rather one ought to consider that a small increase in a highly industrialized population has a much greater impact on the environment, in terms of both pollution and demand on natural resources, than a corresponding increase in a nonindustrialized nation. Nor should one overlook the folly of failing to practise what one preaches. It is easy for undeveloped nations to misinterpret the motives of someone who urges "one law for the rich and another for the poor"

Finally, we should like to emphasize the distinction which exists between "family planning" programmes designed to allow any woman the freedom to choose the size of her family and effective population control.

Yours faithfully,

C. J. BOLTON

J. E. CORDWEll

60 Parklands,

Wotton-under-Edge,

Gloucestershire GL12 7NR

\section{Institute of Hydrology}

SIR,--The italicized postscript to the feature article "Lord Rothschild and the
Institute of Hydrology" (Nature, 235, 8 ; 1972) states:

"The Rothschild report also recommends that the Nature Conservancy, now part of the Natural Environment Research Council (NERC), should be transferred as a whole to the Department of the Environment."

In fact, the Rothschild report made no such recommendation. What is recommended was:

"The whole of the Countryside programme should be financed by the DOE and SDD, which explains why the Nature Conservancy (excluding basic ecological research $(£ 0.25 \mathrm{~m})$ ) should be paid for by these Departments."

As the article itself correctly states, only the Institute of Hydrology among all the institutes of all the Research Councils is recommended for physical transfer, together with its staff, to a Department. It is the purpose of the article to describe the true nature and aims of the work in progress at the Institute, which consists largely of basic hydrological research.

Yours faithfully,

R. J. H. BEVERTON

Natural Environment Research Council, Alhambra House,

27-33 Charing Cross Road,

London $W C 2$

\title{
Obituary
}
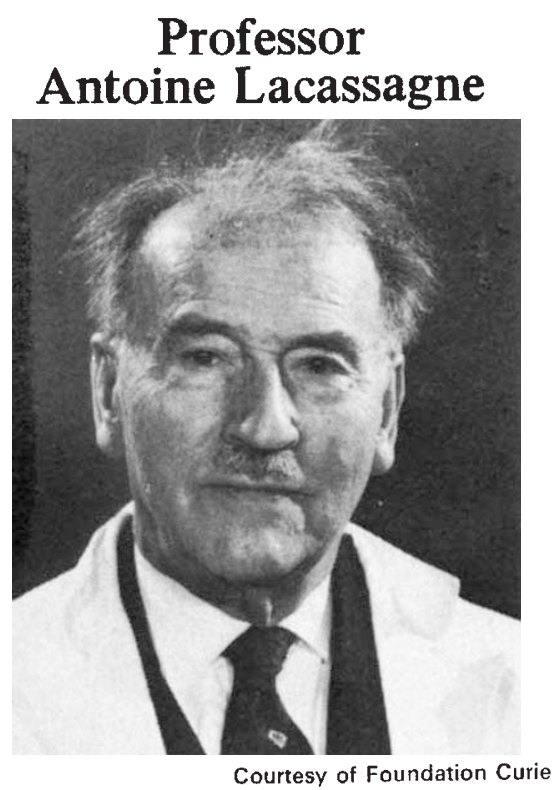

Professor Lacassagne, French pioneer in radiology and cancer research, died in Paris on December 16, 1971.

Antoine Lacassagne was born at Vil- lerest (Loire) on August 29, 1884 . He came of a medical family, his father having been a military physician and Professor of Legal Medicine in the Faculty of Medicine and Pharmacy of the University of Lyon. Doctor of medicine and intern of the hospitals of Lyon, in 1908 Professor Lacassagne entered the Laboratory of Histology to work under the direction of Claudius Regaud. He made the subject of his first scientific work "Histological and Physiological Studies of the Effects Produced on the Ovary by X-irradiation". In 1909 Dr Regaud was recalled to Paris by Emile Roux, Director of the Institut Pasteur, to take charge of the recently constructed Laboratory of Radiophysiology, Pasteur Laboratory of the Institut du Radium. In 1913 Regaud in turn sent for his pupil, Lacassagne, to install him in the new venture. Mobilized in 1914 Lacassagne then spent four years as medical auxiliary at the front, notably in Greece and Roumania. He returned to the Institut du Radium in 1919 where he served to the end of his life. He was nominated Assistant Director of the Pasteur Laboratory in 1923. In 1937 Regaud retired and Lacassagne succeeded him as Chef de Service of the Institut Pasteur and Director of the Section of Biology of the Institut du Radium. At the same time he became Director of Research in the Fondation Curie which had been founded in 1921 as a department for the practical application of the work of the Institut du Radium. These positions he held until his retirement in October 1954. In 1941 he was elected Professor of Radiobiology and Cancerology in the Collège de France. Also in that year came his election to the Académie des Sciences. Retirement did not diminish his activity, and he retained a laboratory in the Institut du Radium where $R$. Latarjet had succeeded him. In 1957, on the death of Justin Godard, he became President of the Ligue Nationale Française contre le Cancer and remained in this post till the time of his death. In 1950 Lacassagne acted as President of the Fifth 